\title{
KAJIAN INDUKSI KALUS RUMPUT LAUT Kappaphycus alvarezii UNTUK PRODUKSI EMBRIO SOMATIK
}

\author{
Muh. Alias L. Rajamuddin"), Andi Asdar Jaya"), Ridwan*), dan Emma Suryati"*) \\ *) Jurusan Budidaya Perikanan, Politeknik Pertanian Negeri Pangkep \\ Jl. Poros Makassar-Pare Pare (km. 83) Mandalle, Pangkep \\ E-mail: mal_rajamuddin@yahoo.co.id \\ ${ }^{* *}$ Balai Riset Perikanan Budidaya Air Payau \\ Jl. Makmur Dg. Sitakka No. 129, Maros 90512, Sulawesi Selatan
}

(Naskah diterima: 13 April 2010; Disetujui publikasi: 13 Agustus 2010)

\begin{abstract}
ABSTRAK
Untuk mendukung program transgenesis pada rumput laut, embrio somatik dapat digunakan sebagai material untuk transfer gen baik secara individu sel ataupun kluster sel embriogenik, sehingga mempercepat keberhasilan dengan peluang transformasi yang lebih tinggi. Penelitian ini bertujuan untuk mengkaji induksi kalus rumput laut $K$. alvarezii untuk produksi sel embrio somatik (e.s.) dengan beberapa rasio zat pengatur tumbuh (ZPT) dan konsentrasi agar media induksi, sampai sel menjadi filamen. Penelitian terdiri atas dua tahap: Tahap (1) induksi kalus, dengan rasio ZPT asam indol asetat (IAA): kinetin = 0,5:0,0 mg/L; 1,0:1,0 mg/L; dan 2,0:0,2 mg/L dengan konsentrasi agar media induksi = 0,6\%; 0,8\%; 1,0\%; dan 1,5\%. Tahap (2) regenerasi massa sel e.s., dengan rasio IAA:kinetin $=0,1: 1,0 \mathrm{mg} / \mathrm{L} ; 0,0: 0,1 \mathrm{mg} / \mathrm{L}$ dan tanpa ZPT dengan konsentrasi agar media $=0,4 \%$; 0,6\%; dan 0,8\%. Untuk perkembangan sel-sel e.s. lebih lanjut dipelihara pada kultur cair. Hasil penelitian menunjukkan pada tahap induksi kalus, rasio IAA: kinetin $=1: 1 \mathrm{mg} / \mathrm{L}$ dengan konsentrasi agar media $0,8 \%$ dan $1,0 \%$ menghasilkan persentase induksi kalus tertinggi (90\%). Pada tahap regenerasi massa sel e.s., ZPT tidak berpengaruh terhadap perkembangan massa sel e.s., di mana tanpa ZPT dengan konsentrasi agar 0,6\% memperlihatkan perkembangan tertinggi (rata-rata diameter massa sel $5 \mathrm{~mm}$ ). Pada media cair, perkembangan sel e.s. dari single cell ukuran 3-4 mm menjadi filamen-filamen ukuran rata-rata 0,5 $\mathrm{mm}$ dapat dicapai dalam satu bulan kultur. Keberhasilan produksi sel e.s. K. alvarezii, selain sebagai material untuk transfer gen juga dapat dijadikan acuan dalam produksi benih rumput laut kultur jaringan.
\end{abstract}

KATA KUNCI: Kappaphycus alvarezii, kalus, embrio somatik

ABSTRACT: Callus induction of Kappaphycus alvarezii for somatic embryo production. By: Muh. Alias L. Rajamuddin, Andi Asdar Jaya, Ridwan, and Emma Suryati

To support the program of seaweed transgenesis, somatic embryo can be used as a materials for gene transfer purpose either by individual or cluster of cells in accelerating the higher rate of transformation. This research aims to study the callus induction of seaweed $K$. alvarezii for production of somatic embrio (s.e) cell by different ratio of growth regulators (GR) and agar media concentrations. The study consists of two stages: stage (1) callus induction to the cells filament using GR of indol acetic acid (IAA):kinetin in ratio of $0.5: 0.0 \mathrm{mg} / \mathrm{L} ; 1.0: 1.0 \mathrm{mg} / \mathrm{L} ;$ and $2.0: 0.2 \mathrm{mg} / \mathrm{L}$ on the media agar concentration of $0.6 \% ; 0.8 \% ; 1.0 \%$; and $1.5 \%$, and stage (2) regeneration of the cell mass of s.e, using GR of IAA:kinetin in ratio of $0.1: 1.0 \mathrm{mg} / \mathrm{L} ; 0.0: 0.1 \mathrm{mg} / \mathrm{L} \mathrm{on}$ the media agar concentration of $0.4 \%$; $0.6 \%$; and $0.8 \%$. For further maintenance, the s.e cells were cultured in liquid media. The results of callus induction showed that the 
ratio of IAA:kinetin (1:1) on the media agar concentration of $0.8 \%$ and $1.0 \%$ produced the highest callus induction (90\%). The study of mass cell regeneration of s.e showed did not different of GR IAA:kinetin ratio of the cell mass development, but the media agar concentration of $0.6 \%$ and $0.4 \%$ showed the higher growth of cell mass (in diameter size of 4-5 mm). The development of cells culture of s.e from the size of 3-4 $\mathrm{mm}$ to filament of $0.5 \mathrm{~mm}$ could be reached in one month of culture period. The success of $K$. alvarezii s.e production will be helpful not only as a material for gene transfer but also as a reference on tissue culture for seed production of seaweed.

\section{KEYWORDS: Kappaphycus alvarezii, callus, somatic embryo}

\section{PENDAHULUAN}

Rumput laut merupakan salah satu komoditas utama program revitalisasi Kementerian Kelautan dan Perikanan RI yang diharapkan berperan penting dalam peningkatan kesejahteraan masyarakat. Beberapa keunggulan usaha budidaya rumput laut adalah: sistem produksi tidak membutuhkan teknologi yang rumit, dilakukan secara manual dan dapat dikembangkan sebagai usaha padat karya, siklus produksi yang pendek (45 hari) sehingga cepat menghasilkan pendapatan, penanganan pasca panen mudah, murah, tidak membutuhkan sarana khusus dan dapat disimpan dalam waktu lama (Othmer, 1968; Anggadiredja et al., 2006; DPB-DKP, 2008). Untuk terus meningkatkan dan mempertahankan produksi rumput laut nasional perlu dilakukan upaya-upaya dalam mengatasi permasalahan budidaya, seperti: menurunnya mutu genetik rumput laut akibat permasalahan penyakit dan lingkungan (Largo et al., 1997; Vairappan, 2006) dengan beberapa pendekatan teknologi, antara lain rekayasa genetik (transgenesis).

Untuk mendukung program pemuliaan tanaman melalui rekayasa genetika (transgenesis), embrio somatik dapat digunakan sebagai material genetik untuk transfer gen baik secara individu sel ataupun kluster sel embriogenik sehingga dapat mempercepat keberhasilan dengan peluang transformasi yang lebih tinggi, suspensi sel embriogenik juga dapat digunakan sebagai bahan untuk kultur protoplas (Supena, 2008). Embriogenesis somatik yaitu proses terbentuknya embrio somatik, embrio yang terbentuk bukan dari zigot tetapi dari sel biasa dari tubuh tanaman (Ammirato, 1983; Gunawan, 1987). Embriogenesis somatik merupakan suatu proses di mana sel somatik (baik haploid maupun diploid) berkembang membentuk tumbuhan baru melalui tahap perkembangan embrio yang spesifik tanpa melalui fusi gamet (Hamama et al., 2001).

Penggandaan biakan dalam kultur jaringan, eksplan yang ditanam pada media tumbuh yang tepat dapat beregenerasi melalui jalur embriogenesis somatik. Embrio somatik dapat terbentuk melalui dua jalur, yaitu secara langsung maupun tidak langsung melewati fase kalus (Gaj, 2001). Kemampuan jaringan membentuk kalus dan laju pertumbuhan kalus tergantung pada medium, zat pengatur tumbuh (ZPT) yang digunakan dan faktor lingkungan lainnya. Penelitian ini bertujuan untuk mengkaji induksi kalus rumput laut untuk produksi sel-sel embrio somatik (e.s.) dengan beberapa rasio zat pengatur tumbuh (ZPT) dan konsentrasi agar media induksi, sampai sel menjadi filamen.

\section{BAHAN DAN METODE}

\section{Inisiasi, Proliferasi, dan \\ Pemeliharaan Sumber Inokulum}

Tahap ini bertujuan untuk menyediakan sumber inokulum bagi penelitian tahap 1: Rumput laut hasil budidaya dari lapangan dicuci dengan air laut sampai bersih kemudian dipotong-potong 2-3 cm (eksplan), ditampung pada botol yang berisi air laut steril. Eksplan selanjutnya dibilas larutan betadin 1\% kemudian dicuci air laut steril sampai 3 kali. Sterilisasi eksplan dilanjutkan dengan 0,1\% antibiotik mix spektrum luas (streptomisin, kanamisin, terramisin, rifampisin, penisilin G) kemudian dicuci air laut steril sampai 3 kali. Untuk inisiasi, proliferasi dan pemeliharaan sekaligus menguji stabilitas eksplan sebelum digunakan, dapat dikarantina terlebih dahulu dengan memelihara pada air laut steril yang mengandung media tumbuh Conway $2 \mathrm{mg} / \mathrm{L}$ pada suhu ruang $25^{\circ} \mathrm{C}$ dengan intensitas cahaya 1.500 lux dan di-shaker dengan kecepatan 100 rpm. 
Tahap 1. Induksi dan pembentukan kalus

Potongan thallus (eksplan) yang telah diiris setebal 2-3 mm, sebanyak 10 irisan setiap botol dipelihara pada botol kultur steril yang berisi $20 \mathrm{~mL}$ media agar pada beberapa konsentrasi yaitu: $0,6 \% ; 0,8 \% ; 1,0 \%$; dan 1,5\%. Media perlakuan terdiri atas media kultur Conway $2 \mathrm{mg} / \mathrm{L}$ dan masing-masing ditambah dua jenis zat pengatur tumbuh (ZPT) IAA:kinetin dengan tiga taraf rasio yaitu: $0,5: 0,0 \mathrm{mg} / \mathrm{L}$; 1,0:1,0 mg/L; 2,0:0,2 mg/L. Selanjutnya botol kultur berisi biakan ditutup dengan baik dan dilapisi plastik pembungkus makanan (cling wrap) untuk menghindari kontaminasi. Biakan diletakkan dan dipelihara dalam ruang kultur pada suhu ruang $25^{\circ} \mathrm{C}$, intensitas cahaya 1.500 lux. Pemeliharaan dilakukan selama 2 (dua) bulan atau sampai induksi kalus stabil, di mana pergantian media kultur dilakukan setiap 30 hari dengan media baru yang sama. Untuk melihat efesiensi induksi kalus dihitung berdasarkan persentase jumlah eksplan yang terinduksi setiap botol. Pengamatan secara mikroskopik dilakukan untuk memastikan kaluskalus hasil induksi mengandung sel-sel embrio somatik serta mengamati perkembangannya. Tahapan-tahapan perkembangan sel embrio somatik didokumentasikan dengan bantuan peralatan foto untuk keperluan analisis deskriptif.

\section{Tahap 2. Regenerasi massa sel embrio somatik}

Setelah dua bulan kultur pada tahap 1, kalus-kalus yang mengandung sel-sel embrio somatik dikultur lebih lanjut pada dua tahapan regenerasi yaitu pada media agar semi solid dan kultur cair:

\section{Kultur sel embrio somatik pada media agar semi solid}

Kalus diiris tipis dan disubkultur ke dalam petridish yang berisi media conway sebanyak $20 \mathrm{~mL}$ dengan penambahan zat pengatur tumbuh (ZPT) IAA:kinetin pada beberapa rasio yaitu: 0,1:1.0 mL; 0,0:0,1 mg/L, dan tanpa keduanya dengan persentase agar media berbeda yaitu: 0,4\%; 0,6\%; dan 0,8\%. Petridish berisi kultur ditutup dengan baik dan dilapisi plastik pembungkus makanan (cling wrap) untuk menghindari kontaminasi. Selanjutnya dipelihara dalam ruang kultur pada suhu ruang $25^{\circ} \mathrm{C}$ dengan intensitas cahaya 1.500 lux. Masa pemeliharaan selama 2 (dua) bulan dengan pergantian media kultur dilakukan setiap 40-45 hari dengan media baru yang sama. Perkembangan massa sel embrio somatik diukur menggunakan mistar geser dan sel-sel embrio somatik di-sampling dan diamati di bawah mikroskop, panjang sel diukur menggunakan bantuan mikrometer okuler dan didokumentasikan serta diuraikan secara deskriptif.

\section{Kultur lanjutan sel embrio somatik pada media cair}

Massa sel embrio somatik yang sudah stabil pada media agar semi solid diangkat dan dipindahkan dengan pinset steril ke dalam conical flask yang berisi media kultur cair air laut steril diperkaya Conway $2 \mathrm{mg} / \mathrm{L}$ tanpa ZPT untuk diferensiasi lebih lanjut. Conical flask selanjutnya diletakkan di ruang kultur dan dishaker dengan kecepatan 100 rpm, dengan lama pemeliharaan satu bulan atau sampai terbentuk seperti filamen (bakal planlet). Selama pemeliharaan, setiap dua minggu dilakukan sampling secara aseptik untuk mengamati perkembangan selnya.

\section{HASIL DAN BAHASAN}

\section{Tahap 1. Induksi dan pembentukan kalus}

Pada tahapan induksi kalus, eksplan yang terinduksi ditandai dengan tumbuhnya massa sel yang tidak terorganisir, sel tumbuh keluar dari eksplan, dengan jenis dan tipe kalus friable atau remah (Gambar 1A), sedangkan eksplan yang gagal induksi ditandai dengan tidak terbentuknya kalus, bahkan eksplan mengalami pemucatan dan akhirnya mati (Gambar 1B). Hasil penelitian menunjukkan (Gambar 2) bahwa induksi kalus tertinggi diperoleh pada rasio IAA:kinetin $=1,0: 1,0$ $\mathrm{mg} / \mathrm{L}$ dengan konsentrasi agar media $0,8 \%$ $(90 \% \pm 0,0 \%)$ dan $1,0 \%(90 \% \pm 10,0 \%)$.

$\mathrm{Hal}$ ini dapat berlangsung karena keseimbangan rasio ZPT antara IAA dan kinetin, di mana keduanya dibutuhkan dalam proses induksi. Peran IAA yang (tergolong kelompok ZPT auksin) terlibat dalam banyak proses fisiologis tumbuhan, antara lain: pemanjangan sel dan pembentukan kalus (Harjadi, 2009) dan juga atas sinergisitas peran dari kinetin (tergolong kelompok ZPT sitokinin) di mana peran fisiologis sitokinin adalah mendorong pembelahan sel, morfogenesis, dan pembentukan kloroplas (Wiendi et al., 1991; Wattimena et al., 1992). 

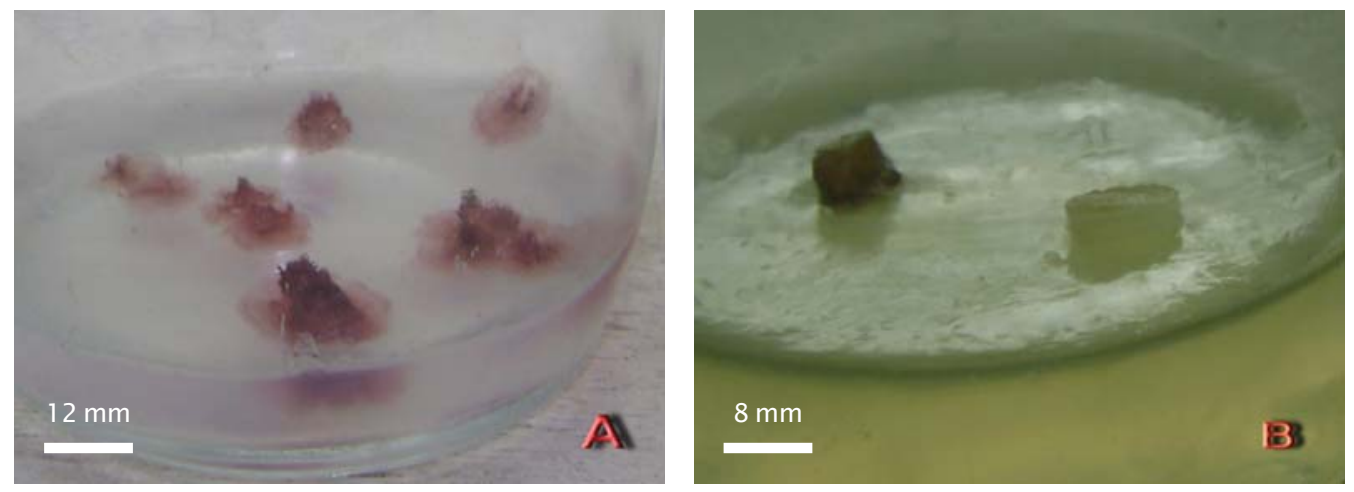

Gambar 1. Karakteristik induksi kalus pada rumput laut K.alvarezii. Morfologi eksplan yang terinduksi (A), dan yang tidak terinduksi (B)

Figure 1. Characteristics of callus induction on K. alvarezii. Morphology of explants induced $(A)$, and which are not induced (B)

Tingkat induksi kalus pada rasio ZPT IAA: kinetin $=0,5: 0,0 \mathrm{mg} / \mathrm{L}$ dengan konsentrasi agar media 1,5\% menghasilkan tingkat induksi lebih rendah dari perlakuan lainnya $(50 \% \pm$ $10,0 \%$, hal ini diduga karena tidak ditambahkannya kinetin $(0 \mathrm{mg} / \mathrm{L})$ sementara peran fisiologisnya tetap dibutuhkan dalam proses induksi kalus walaupun dalam jumlah kecil. Keberhasilan induksi kalus pada penelitian ini sedikit lebih tinggi daripada yang dilaporkan oleh Reddy et al. (2003), di mana tingkat induksi kalus tertinggi yang diperoleh (80\%) dengan kombinasi ZPT NAA:BAP (1:1 mg/L).
Hasil penelitian ini juga menunjukkan bahwa tingginya tingkat induksi didukung oleh konsentrasi agar yang sesuai. Pada konsentrasi $0,8 \%$ dan 1,0\% merupakan konsentrasi agar media induksi yang sesuai untuk induksi kalus $K$. alvarezii. Hal ini diduga disebabkan karena pada konsentrasi agar media induksi terlalu tinggi $(1,5 \%)$ menyebabkan tingkat kerapatan dan kepadatan massa media juga tinggi mempengaruhi tingkat penyerapan nutrien sehingga secara tidak langsung berpengaruh pada proses induksi (Suryati \& Mulyaningrum, 2009). Selanjutnya dijelaskan

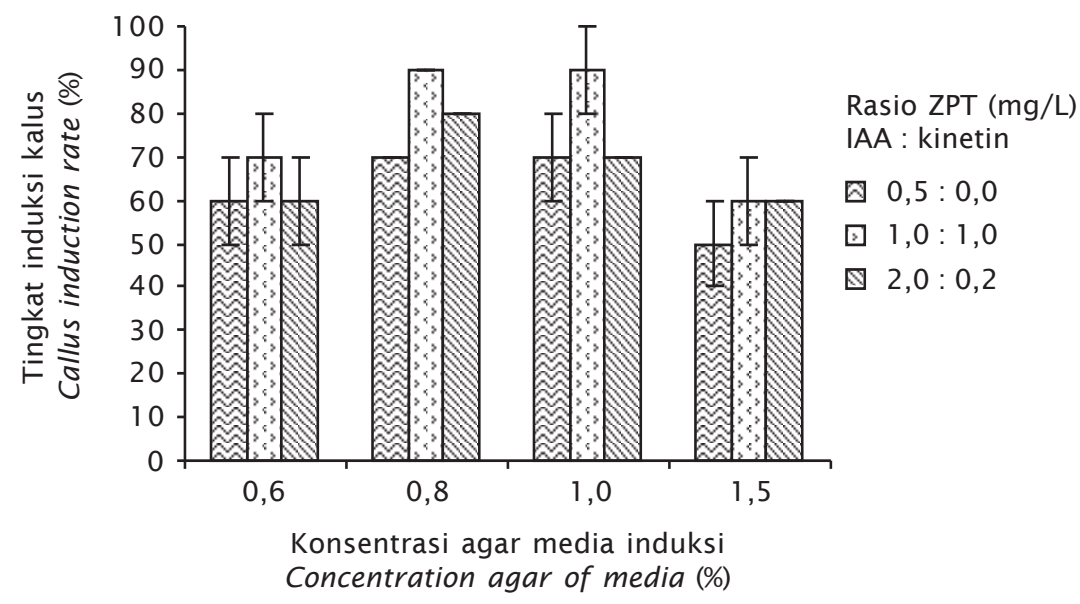

Gambar 2. Pengaruh perlakuan rasio ZPT dan konsentrasi agar media terhadap tingkat induksi kalus

Figure 2. Effect of growth regulator ratio and the concentration agar of media to callus induction rate 
bahwa konsentrasi agar media yang terlalu rendah $(0,6 \%)$ dapat menyebabkan porisitas, kekenyalan, dan kepadatan massa media sangat labil. Namun demikian tingkat induksi pada konsentrasi agar media 0,6\% masih lebih baik dari konsentrasi agar media 1,5\%. Penelitian Suryati \& Mulyaningrum (2009) memperoleh tingkat induksi hanya $30 \%$ pada konsentrasi agar media 0,6; banyak eksplan mengalami pemucatan sampai kematian dan pada konsentrasi agar 1,2\% eksplan mengalami dehidrasi dan akhirnya juga mengalami kematian.

\section{Tahap 2. Regenerasi massa sel embrio somatik}

\section{Kultur sel embrio somatik pada media agar semi solid}

Hasil pengamatan (Gambar 3) menunjukkan bahwa pada kultur lebih lanjut di media agar semi solid, ZPT tidak memberikan pengaruh antar perlakuan terhadap penambahan massa sel embrio somatik $(P>0,05)$. Hal ini menunjukkan bahwa zat pengatur tumbuh bukan faktor pembatas untuk perkembangan lebih lanjut dari massa sel embrio somatik rumput laut $K$. alvarezii.

Perkembangan massa sel embrio somatik tertinggi (rata-rata diameter massa sel $=5 \pm 1,0$ $\mathrm{mm}$ ) diperoleh pada perlakuan tanpa ZPT dengan konsentrasi agar 0,6\% untuk masa pemeliharaan 1 (satu) bulan (Gambar 4B), dan yang terendah diperoleh dari perlakuan ZPT rasio IAA:kinetin $=0,1: 1,0$ dengan konsentrasi agar media 0,8\% (rata-rata diameter massa sel $=3 \pm 1,0 \mathrm{~mm}$ ), sedangkan perlakuan lainnya ratarata diameter massa sel adalah $4 \mathrm{~mm}$, di mana massa sel embrio somatik pada awal kultur masing-masing rata-rata $1 \mathrm{~mm}$ (Gambar 4A).

Pada konsentrasi 0,6\% merupakan konsentrasi agar media pemeliharaan yang sesuai untuk regenerasi massa sel embrio somatik pada media semi solid. Hal ini disebabkan perkembangan awal sel membutuhkan porositas dan kerapatan media yang rendah sehingga menunjang laju pertumbuhan yang maksimal. Penelitian Reddy et al. (2003) dan Zhao et al. (2009) diperoleh hasil perkembangan massa sel antara 1-5 mm dengan masa pemeliharaan yang sama.

Wattimena et al. (1992) menyebutkan bahwa pada awal proses embriogenesis untuk menghasilkan sel embriogenik yang viabel, jaringan atau sel perlu dilakukan subkultur ke media dengan auksin rendah atau tanpa auksin sama sekali, bahkan kultur yang terlalu lama pada media dengan auksin tinggi sebelum disubkultur dapat menghilangkan daya embriogenesisnya.
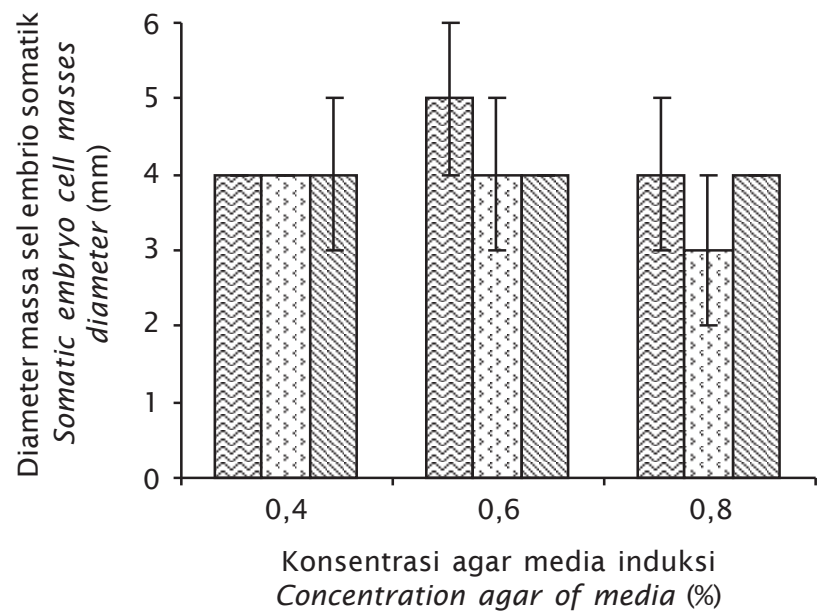

Rasio ZPT (mg/L)

IAA : kinetin

因 $0,5: 0,0$

曰 $1,0: 1,0$

圆 $2,0: 0,2$

Concentration agar of media (\%)

Gambar 3. Perkembangan massa sel embrio somatik pada tahap regenerasi pada berbagai rasio ZPT dan konsentrasi agar media

Figure 3. Development of somatic embryo cell masses at the stage of regeneration at different growth regulators ratios and concentrations agar of media 

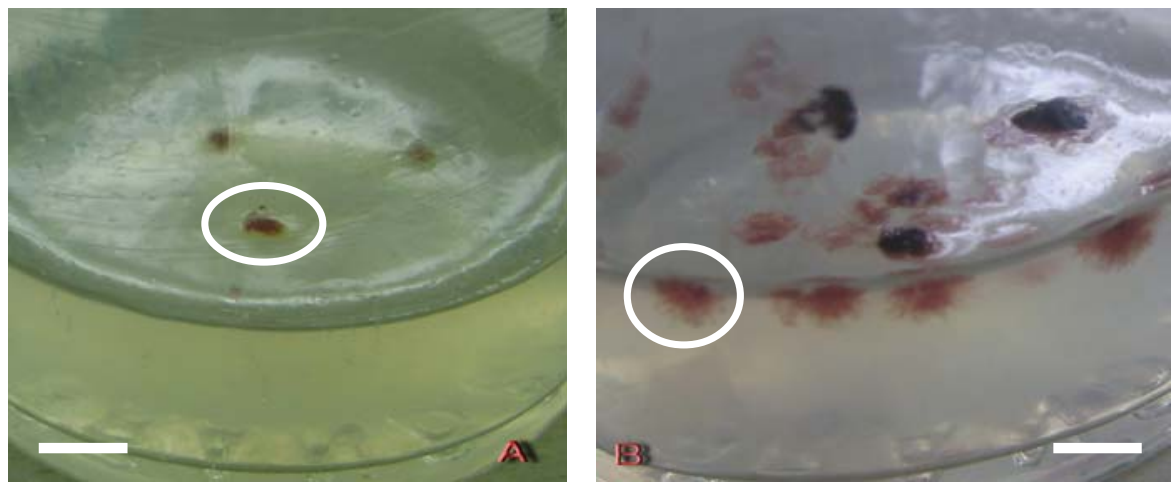

Gambar 4. Perkembangan massa sel embrio somatik K. alvarezii pada kultur media agar semi solid: A. Massa sel pada hari-1 kultur (bar $=1 \mathrm{~mm}$ ), B. Massa sel pada umur 1 bulan kultur (bar $=5 \mathrm{~mm}$ ). Tanda bulatan menunjukkan massa sel embrio somatik

Figure 4. Development of somatic embryogenic cell masses $K$. alvarezii on semi solid agar media culture: $A$. Cell mass at first day of culture (scale bar = $1 \mathrm{~mm}$ ), B. Cell mass at the age of 1 month of culture (scale bar $=5 \mathrm{~mm}$ ). Rounded showed of somatic embryo cell mass

\section{Kultur lanjutan sel embrio somatik pada media cair}

Hasil pengamatan di bawah mikroskop, sel embrio somatik terbentuk sebagai tunas baru dari permukaan sel dan memanjang ke daerah apikal dari filamen (Gambar 5A), berasal dari sel dengan ukuran 3-5 mm selanjutnya berkembang menjadi filamen baru sebagai bakal rumput laut muda (Gambar 5B). Perkembangan sel embrio somatik dari sel tunggal dengan ukuran 3-4 mm, menjadi dua sel, tiga sel, empat sel, dan selanjutnya berkembang menjadi filamen (Gambar 6) dengan masa kultur 1 (satu) bulan terjadi pemanjangan sel baru rata-rata $5 \mathrm{~mm}$ ( Gambar 7).
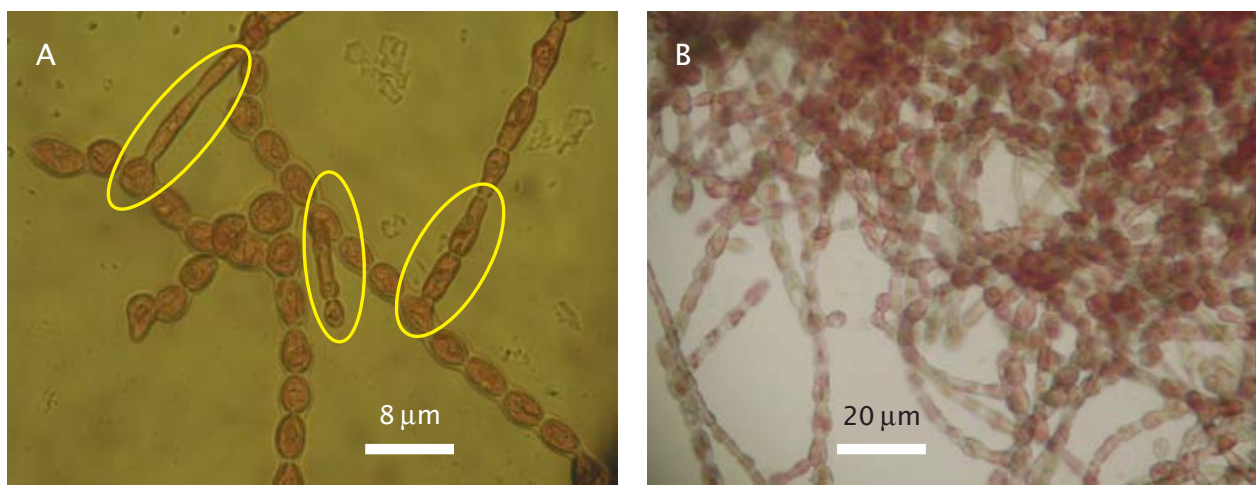

Gambar 5. (A) Tanda bulatan: sel embrio somatik berupa tunas baru yang tumbuh dari sel dan memanjang ke daerah apikal dari filamen, (B) Filamen yang merupakan kumpulan se-sel embrio somatik sebagai calon $K$. alvarezii muda

Figure 5. (A) Rounded showed: somatic embryos usually occurred as tyni buds on the surface of elongated cells near apical regions of the filaments, (B) Filaments which is a collection of somatic embryo cells as a potential young $K$. alvarezii 

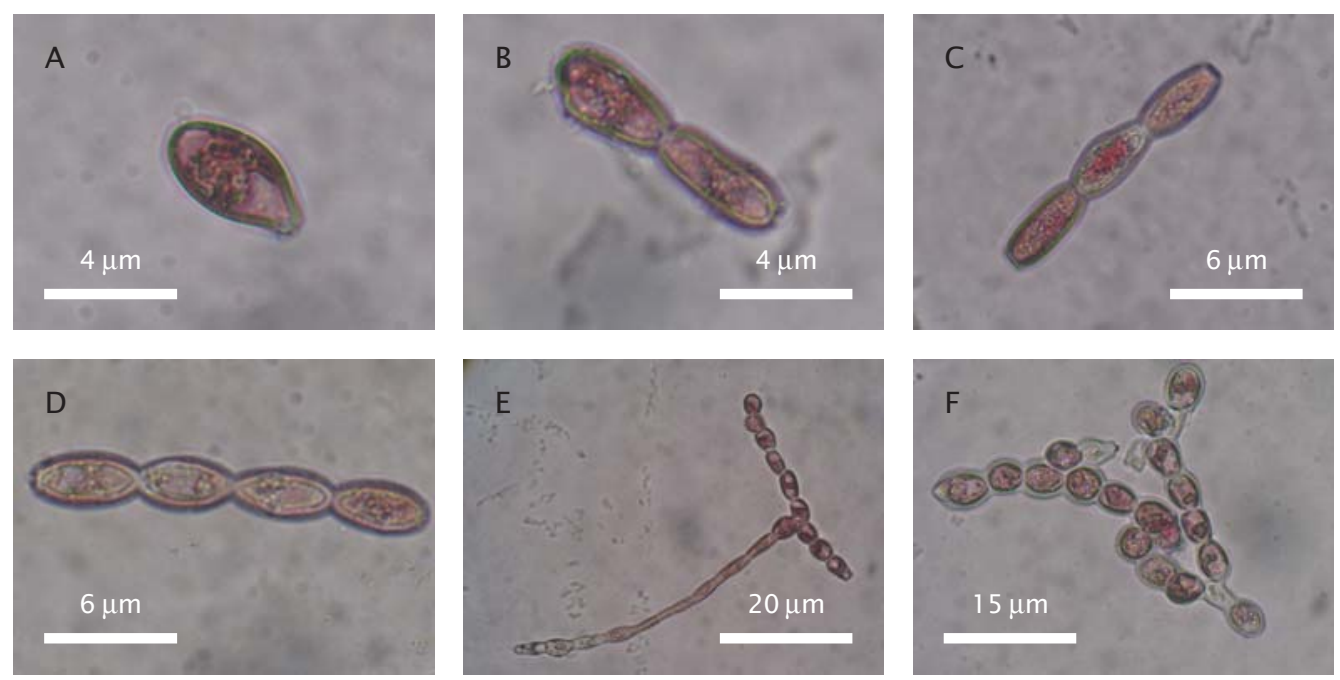

Gambar 6. Perkembangan sel embriogenik somatik K. alvarezii : (A) sel tunggal, (B) dua sel, (C) tiga sel, (D) empat sel, (E\& F) menjadi filamen

Figure 6. Development of somatic embryogenic cells K. alvarezii: (A) single cell, (B) two cells, (C) three cells, (D) four cell, (E \& F) into filaments

Pada penelitian Reddy et al. (2003) menyebutkan bahwa embrio somatik terjadi sebagai tunas kecil di atas permukaan dari selsel dan memanjang ke daerah apikal dari filamen. Tunas ini berasal dari satu sel tunggal yang kecil dengan ukuran $<10 \mathrm{~mm}$ dengan ciri-ciri berisi sitoplasmik padat dan pigmentasi.
Sel embrio somatik, selain pada fase ini dapat digunakan sebagai agen introduksi gen untuk kegiatan transgenesis rumput laut, juga dapat digunakan untuk kultur lebih lanjut menjadi calon rumput laut muda. Beberapa kelebihan embrio somatik antara lain berasal dari individu sel (satu sel somatik) sehingga penyeragaman dan pemurnian tanaman

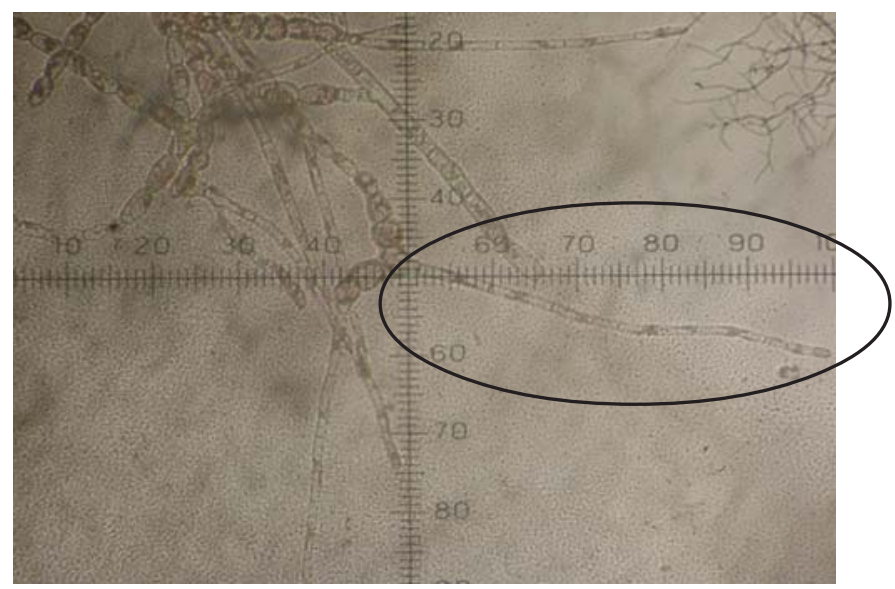

Gambar 7. Tanda bulatan : pemanjangan sel baru rata-rata 0,5 mm pada umur 1 bulan dikultur cair

Figure 7. Rounded showed: elongation of new cells on average $0.5 \mathrm{~mm}$ at the age of 1 month in liquid culture 
regeneran lebih mudah (Bhojwani \& Razdan, 1989; Supena, 2008). Suspensi sel embrio somatik dapat digunakan sebagai bahan untuk kultur protoplas (Anhazhagan \& Ganapathi, 1999), dapat digunakan sebagai material untuk transfer gen baik secara individu sel ataupun kluster sel embrio somatik, sehingga dapat mempercepat keberhasilan dengan peluang transformasi yang lebih tinggi (Supena, 2008).

\section{KESIMPULAN}

Tahap induksi kalus, rasio zat pengatur tumbuh (ZPT) IAA: kinetin = 1,0:1,0 mg/L pada konsentrasi agar $0,8 \%$ dan 1,0\% menghasilkan persentase induksi kalus tertinggi (90\%). Tahap regenerasi massa sel embrio somatik pada kultur lebih lanjut di media agar semi solid, ZPT tidak berpengaruh terhadap perkembangan massa sel embrio somatik. Perkembangan sel-sel embrio somatik $K$. alvarezii, sel tunggal dengan ukuran 3-4 mm dan perkembangan filamen-filamen pada kultur cair dengan pemanjangan sel baru ratarata $0,5 \mathrm{~mm}$ dalam masa kultur 1 bulan.

\section{UCAPAN TERIMA KASIH}

Penelitian ini terlaksana atas biaya hibah penelitian (Research Grant) I-MHERE Project Politeknik Pertanian Negeri Pangkep tahun 2009 serta atas dukungan Balai Riset Perikanan Budidaya Air Payau (BRPBAP), Maros dan Laboratorium Kultur Jaringan-Pusat Penelitian Sumberdaya Hayati dan Bioteknologi, Institut Pertanian Bogor.

\section{DAFTAR ACUAN}

Ammirato, P.V. 1983. Embryogenesis. In Evans, D.A., Sharp, W.R., Ammirato, P.V., \& Yamada, Y. (Eds.). Handbook of Plant Cell Culture, 1: 82-123.

Anggadiredja, J.T., Achmad, Z., Heri, P., \& Sri, I. 2006. Rumput Laut. Penebar Swadaya, 145 $\mathrm{hlm}$.

Anhazhagan, V.R. \& Ganapathi, A. 1999. Somatic embryogenesis in cell suspension cultures of pigeon (Cajanus cajan). Plant Cell, Tissue, and Organ Culture, 56: 179184.

Bhojwani, S.S. \& Razdan, M.K. 1989. Plant Tissue Culture. Theory and Practise. Elsevier, New York, 776 pp.

[DPB-DKP] Dirjen Perikanan Budidaya Departemen Kelautan Perikanan. 2008. Makalah pada Seminar Nasional "Sense of
Aquaculture". Institut Pertanian Bogor, 15 Desember 2008, $61 \mathrm{hlm}$.

Gaj, M.D. 2001. Direct somatic embryogenesis as a rapid and efficient system for in vitro regeneration of Arabidopsis thaliana. Plant Cell and Organ Culture, 64: 39-46.

Gunawan, L.W. 1987. Teknik Kultur Jaringan. Laboratorium Kultur Jaringan Tanaman. Pusat Antar Universitas (PAU) Bioteknologi. Institut Pertanian Bogor, $245 \mathrm{hlm}$.

Hamama, L., Baasiz, M., \& Letouze, R. 2001. Somatic embryogenesis and plant regeneration from leaf tissue of jojoba. Plant Cell and Organ Culture, 65: 109-113.

Harjadi, S.S. 2009. Zat Pengatur Tumbuh. Pengenalan dan Petunjuk Penggunaan pada Tanaman, $76 \mathrm{hlm}$.

Largo, D.B., Fukami, K., Adachi, M., \& Nishijima, T. 1997. Direct enumeration of total bacteria from macroalgae by epifluorescence microscopy asapplied to the fleshy red algae Kappaphycus alvarezii and Gracilaria spp. (Rhodophyta). J. Phycol., 33: 554-557.

Othmer. 1968. Seaweed Colloids. Encyclopedia of Chemical Technology, 17: 763-784.

Reddy, C.R.K., Kumar, G.R.K., Siddhanta, A.K., \& Tewari, A. 2003. In Vitro Somatic Embriogenesis and Regeneration of Somatic Embryos from Pigmented Callus of Kappaphycus alvarezii (Doty) Doty (Rhodophyta, Gigartinales). J. Phycol., 39: 610-616.

Suryati, E. \& Mulyaningrum, S.R.H. 2009. Regenerasi rumput laut Kappaphycus alvarezii (Doty) melalui induksi kalus dan embrio dengan penambahan hormon perangsang tumbuh secara in vitro. J. Ris. Akuakultur, 4(1): 39-45.

Supena, E.D.J. 2008. Biologi Kultur In Vitro Tumbuhan. Departemen Biologi. Fakultas MIPA. Institut Pertanian Bogor, 75 hlm.

Vairappan, C.S. 2006. Seasonal occurrences of epiphytic algae on the commercially cultivated red alga Kappaphycus alvarezii (Solieriaceae, Gigartinales, Rhodophyta). J. Appl. Phycol., 18:611-617.

Wiendi, N.M.A., Wattimena, G.A., \& Gunawan, L.V. 1991. Perbanyakan Tanaman. Bioteknologi Tanaman I. Pusat Antar Universitas Bioteknologi. Institut Pertanian Bogor, 507 hlm.

Wattimena, G.A., Gunawan, L.V., Nurhayati, A.M., Endang, S., Ni, M.A.W., \& Andri, E. 1992. Bioteknologi Tanaman. Pusat Antar Univer- 
sitas Bioteknologi. Institut Pertanian Bogor, $309 \mathrm{hlm}$.

Zhao, F., Ziguo, Z., Aihua, W., Jidong, L., \& Delin,

D. 2009. Carpospore early development and callus-like tissue induction of Chrysymenia wrightii (Rhodymeniaceae, Rhodophyta) under laboratory conditions. J. Appl. Phycol. 20 May 2009, 8 pp. 